\title{
Economic Crisis And the Fragility of World Wine Export
}

Imre Fertő

Institute of Economics, Centre for Economic and Regional Studies, Hungarian Academy of Sciences, and Kaposvár University, Hungary

\begin{abstract}
The paper investigates the impacts of economic crisis on the duration of word wine exports for 40 leading wine exporter countries between 2000 and 2012. We analyze three attributes of wine exports embodied in exports relationships: the initial value of exports, the growth of exports within a spell, and the hazard of exports ceasing. Our results indicate that wine exports are rather short lived even for leading wine exporter countries. Our estimations imply that economic crisis has not significant impacts on initial value of wine export starting before crisis, whilst it has negative effects on spells beginning after crisis. However, economic crisis does not influence the export growth, and decrease the probability of failure of wine exports.
\end{abstract}

\section{Keywords}

Duration of world wine exports, economic crises, leading wine exporters.

Fertö, I. (2017) "Economic Crisis And the Fragility of World Wine Export", AGRIS on-line Papers in Economics and Informatics, Vol. 9, No. 4, pp. 25-32. ISSN 1804-1930. DOI 10.7160/aol.2017.090403.

\section{Introduction}

During the last two decades, the world's wine market has experienced a rapid process of globalization. Growth in the wine trade boomed during the nineties both in wine consumption in Northern Europe and in North America and in exports of the so-called New World wine producers. Recently, the wine international trade has been boosted by increasing demand in countries (Anderson et al., 2004; Anderson and Nelgen, 2011; Mariani et al., 2012). There is a growing literature on various aspects of recent developments on world wine markets including the impacts tariff and tariff frictions (Mariani et al. 2014; Dal Bianco et al., 2016), dynamics of world wine trade (Castillo et al., 2016), characteristics of intra-EU markets (Fertő et al., 2016; Lombardi et al., 2016).

However, one question is not yet addressed in empirical wine trade literature: when do countries trade and how long do their trade relationships last? Our analysis of this latter issue is, among other things, motivated by the finding of recent research that many countries do not trade in any given year and for any given product (Haveman and Hummels, 2004, Feenstra and Rose, 2000, Schott, 2004). As a consequence of it, a new literature focusing on the duration of international trade has emerged. Based on the surprising finding in Besedeš and Prusa (2006a) that US import flows have a remarkably short duration, the question asked is: "which factors determine how long international trade relationships last?" From a policy-oriented point of view this is indeed an important question to ask. Trade will not grow very much if new products stop being exported after only a few years. Therefore, to better understand which factors may help countries increase their trade, and thereby potentially improve economic development, it is important to learn more about what determines the duration of trade flows. Recent studies provide evidence that trade relationships (e.g. Besedeš and Prusa, 2006b; Nitsch, 2009; Fertő and Soós, 2009; Brenton et al., 2010; Obashi, 2010; Cadot et al., 2013) are surprisingly short lived. Empirical studies usually confirm that exporter characteristics (such as GDP and language), product characteristics (such as unit values) and market characteristics (such as the import value, and market share) affect the duration of trade (Hess and Persson 2011, 2012). However all studies focus only manufacturing or all products except (Bojnec and Fertő, 2012).

In addition, being in or out of the market may be a particularly important issue when the market is affected by external shocks. The economic crisis in 2008 is good natural experiment. Our research focuses on the question how major wine exporter countries in the world market before and after the economic crisis. Specifically, we examine how economic crisis affect the value of wine export 
at the start of a new wine export relationship, the length of wine export relationships, and how quickly wine export grows within a relationship.

\section{Materials and methods}

There are two empirical strands in the international trade literature on the duration of trade. The first analyses the duration of bilateral trade relations at the product (category) level and the second analyses the trade behaviour of firms, in particular switching of export products and destinations. This paper builds upon on the first strand of the literature focusing on country-product relations.

Besedeš and Prusa (2006a) distinguish homogeneous and differentiated goods using the Rauch (1999) classification They find that homogeneous goods have higher hazard rates than differentiated goods and higher initial trade values increase survival. In addition their results indicate lower transportation costs, higher GDP, higher tariffs, and depreciation of the source country's currency all lead to longer durations. Nitsch (2009) applies also Cox proportional hazard models on the duration of German import relations between 1995 and 2005. He also concludes that GDP in the exporting country and a similar language lowers the hazard rate. This is also the case for the initial trade value and market share in the importing country. Brenton et al. (2009) analyse the duration of export flows at the 5-digit SITC level of about 80 exporting countries and 50 importing countries between 1985 and 2005. They also conclude that the initial trade value is important for survival. Hess and Persson (2011) focus on the imports of 15 EU-countries from 140 different exporting countries between 1962 and 2006 at the 4-digit SITC level. They conclude that the mean duration of import flows is only 1 year. Morover they show that export diversification, which - both in terms of the number of products exported and the number of markets served with the given product - substantially lowers the hazard of trade flows dying. Notice, that these studies suffers from the lack of theoretical background. Existing theories based on heterogenous firms does not explain the short lived export relationships (Hess and Persson 2011). More recently Besedeš et al. (2016) provide a theory to explain some empirical regularities of short lived trade relationships.

Following their model we test the following hypotheses. First, the probability of an export relationship ceasing is decreasing in its size and age (or duration). Second, the growth rate of exports is decreasing in size conditional on duration and decreasing in duration conditional on size. Third, larger initial volumes of exports are associated with longer lasting relationships and lower hazard rates. Beyond to theoretical considerations we focus on the impact of the economic crisis on the duration of wine exports. Uncertainties in demand side and cost conditions have important role in export decisions which cannot be resolved after entry of foreign markets. Nguyen (2012) argues that uncertainties may reconcile the high exit rates after first years. We can assume that economic crisis has increased the uncertainties especially on demand side, thus we can expect that crisis has negative impact on the duration of wine exports.

Figure 1 provides a schematic illustration of the types of trade spells a pair of countries can have as they relate to economic crisis, they enter into. The advent of crisis allows us to distinguish between three types of spells. There will be spells such as spell A, which begin and end before the crisis goes into effect. These spells are unaffected by the crisis. There are also spells such as spell B which start before the crisis, but do not end until after the crisis goes into effect. These spells will be directly affected by the crisis. Finally, there are also spells, such as spell C, which start after the crisis has been established.

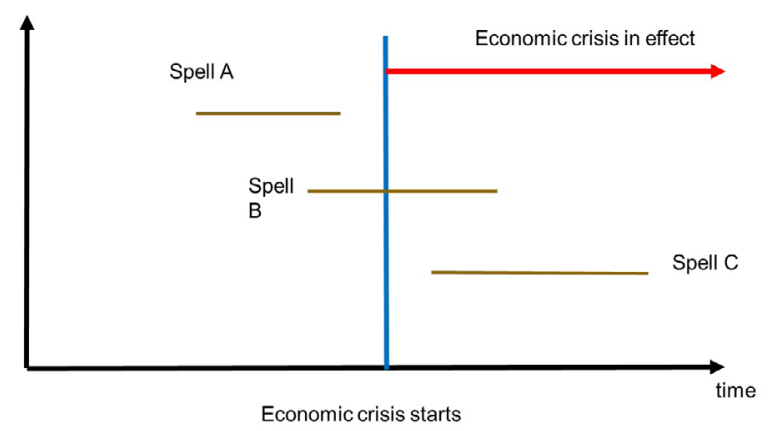

Source: Own compilation

Figure 1: Effects of economic crisis on trade.

To properly identify the effects of economic crisis, we need to differentiate between spells active when the crisis begins and spells which begin after the crisis. In order to properly capture all effects of economic crisis we use two variables. One variable, labeled 'crisis in effect' (Spell B), identifies the years during which crisis is in force, thus identifying the differential effect of the crisis itself. Since model predicts that relationships or spells which start after the crisis are different from already active ones, we use a second dummy variable, 'Spell starts after crisis' (Spell C), which identifies all spells which started after the crisis is put in force. The 'crisis in effect' and 'Spell 
starts after crisis variables in conjunction identify the effect on spells which begin after the crisis is in effect.

We are interested in the effect economic crisis have on three attributes of exports spells: the volume of exports in the first year, the growth of the volume of exports while the spell is active, and the conditional probability it will cease to be active or the hazard rate. We examine the effect on initial volumes and the growth of exports within an active spells by estimating two separate OLS regressions:

$$
\begin{aligned}
& X(1)_{i k t}=\alpha_{0}+\alpha_{1} \text { Crisis }_{t}+\alpha_{2} \text { afterCrisis }_{i k t}+\gamma_{i}+\mu_{k} \\
& +\eta_{t}+\varepsilon_{i k t} \\
& +\alpha_{4} \text { afterCrisis }_{i k t}+\gamma_{i}+\mu_{k}+\eta_{t}+\varepsilon_{i k t}
\end{aligned}
$$

Where $X(1)_{i k t}$ denotes export values in initial period, Xgrowth ${ }_{i k t}$ describes the export growth, $X_{i k t-1}$ is lagged value of exports, Crisis is a dummy takes 1 before 2009, otherwise zero, afterCrisis is a variable reflecting how long the crisis has been in effect when a spell starts, Duration the age of spell $\mathrm{k}$ in year $t, \gamma_{i}$ is exporter fixed effects, $\mu_{k}$ is importer fixed effects and $\eta_{t}$ year fixed effects.

Next step we focus on the duration of world wine exports. Duration analysis of export (export $>0$ ) is estimated by the survival function, $\mathrm{S}(\mathrm{t})$, using the nonparametric Kaplan-Meier product limit estimator (Cleves et al., 2004). We assume that a sample contains $\mathrm{n}$ independent observations denoted $\left(t_{i} ; c_{i}\right)$, where $i=1,2, \ldots, n, t_{\mathrm{i}}$ is the survival time, and $c_{i}$ is the censoring indicator variable $\mathrm{C}$ taking a value of 1 if failure occurred, and 0 otherwise of observation $i$. It is assumed that there are $m<n$ recorded times of failure. The rankordered survival times are denoted as $t\left({ }_{1}\right)<t\left({ }_{2}\right)<\ldots<t\left({ }_{m}\right)$, while $n_{j}$ denotes the number of subjects at risk of failing at $t()_{j}$, and $d_{j}$ denotes the number of observed failures. The Kaplan-Meier estimator of the survival function is then:

$$
\hat{S}(t)=\prod_{t(i)<t} \frac{n_{j}-d_{j}}{n_{j}}
$$

with the convention that $\hat{S}(t)=1$ if $\mathrm{t}<\mathrm{t}(1)$. Given that many observations are censored, it is then noted that the Kaplan-Meier estimator is robust to censoring and uses information from both censored and non-censored observations.

Beyond to descriptive analysis of duration of export, we are interested in the factors explaining the survival. Recent literature on the determinants of trade and comparative advantage duration uses
Cox proportional hazards models (e.g. Besedeš and Prusa, 2006; Bojnec and Fertö, 2012; Cadot et al., 2013). However, recent papers point out three relevant problems inherent in the Cox model that reduce the efficiency of estimators (Hess and Persson, 2011, 2012). First, continuous-time models (such as the Cox model) may result in biased coefficients when the database refers to discretetime intervals (years in our case) and especially in samples with a high number of ties (numerous short spell lengths). Second, Cox models do not control for unobserved heterogeneity (or frailty). Thus, results might not only be biased, but also spurious. The third issue is based on the proportional hazards assumption that implies similar effects at different moments of the duration spell. Following Hess and Persson (2011), we estimate discretetime models, namely probit specifications, where exporter country random effects are incorporated to control for unobservable heterogeneity.

More specifically, we estimate the hazard of exports ceasing at time $\mathrm{t}$ by estimating a discrete hazard using random effects probit specification controlling to origin's and destination's GDP, a vector of bilateral time-invariant gravity variables (distance, common border, and common language)

$$
\begin{aligned}
X D_{i k t} & =\alpha_{0}+\alpha_{1} \text { Duration }_{i k t}+\alpha_{2} X_{i k t-1}+\alpha_{3} \text { Crisist } \\
& +\alpha_{4} \text { afterCrisis }_{i k t}+\alpha_{5} G D P_{i t}+\alpha_{6} G D P_{k t} \\
& +\alpha_{7} \text { lndistance }_{i k}+\alpha_{8} \text { border }_{i k}+\alpha_{9} \text { language }_{i k} \\
& +\varepsilon_{i k t}
\end{aligned}
$$

Our empirical analysis is based on a panel data set includes bilateral trade data of 40 major wine exporter countries and 216 trading partners between 2000-2012, giving 54587 observations. Wine export data comes from the World Bank World Integrated Trade Solution (WITS) database in HS-6 level, product code 2204, in thousand US dollars (World Bank, 2016a). Data for the other explanatory variables are obtained from the following data sources: GDP from the World Bank (2016b) database, trade costs variables including distance, common border and common language are from the CEPII database (Mayer and Zignano, 2011).

\section{Results and discission}

In our aim to explore the duration of wine trade in leading wine exporters countries, we start by performing a thorough descriptive analysis. Table 1 offers some initial summary statistics as to the length of wine exports flows. Notice first that there is a large number of observed spells 
(over 6700). Table 1 shows that the mean duration of a spell in our benchmark data is less than 5 years for the leading wine exporters countries within a relatively short time span (13 years). The mean length of spells starting and ending before crisis (A sample) is rather short less than two years. The average duration of spells surviving crisis (B sample) is relatively long 7.3 years, whilst the length of spells entering into market after crisis is already short (1.8 years). The short lived duration is in line with findings of previous studies (Besedeš and Prusa, 2006b; Besedeš et al., 2016, Bojnec and Fertő, 2012; Nitsch, 2009; Fertő and Soós, 2009; Brenton et al., 2010; Obashi, 2010).

\begin{tabular}{|l|l|c|c|c|c|}
\hline sample & Obs & Mean & Std. Dev. & Min & Max \\
\hline total sample & 6706 & 4.9 & 4.8 & 1 & 13 \\
\hline A sample & 2966 & 1.9 & 1.6 & 1 & 9 \\
\hline B sample & 3740 & 7.3 & 5.2 & 1 & 13 \\
\hline C sample & 1625 & 1.8 & 1.0 & 1 & 4 \\
\hline
\end{tabular}

Source: Own calculations based on World Bank WITS database (2017)

Table 1: Summary statistics of spells.

The left histogram in Figure 1 presents the distribution of the duration density of the number countries with exports $>0$ over the thirteen years analyzed, which is slightly more concentrated on the left side, indicating fewer years continuously being at exports $>0$, than on the right side of the same histogram, indicating more years being continuously at exports $>0$.
Around 22 percent of the wine products have a perfect continued survival rate in exports $>0$ during the thirteen analyzed years.

The right histogram in Figure 2 presents the number of spells with exports $>0$, focusing on the difference between single spells and multiple spells per a given wine product. First, the high share of a single spell with continuous exports $>0$ indicates that most of the main wine exporter countries have a high percentage of wine products that survived a certain number of years in 2000-2012. During the analyzed 13-year period, the minimum length of a spell is one year, and the maximum length of a spell for a given wine exporter countries with continuous exports $>0$ is 13 years. The average value of the length of spell is 4.9 years, while the median value of duration of the spell is only 2 years. Second, among the multiple spells with exports $>0$ per given wine product, two and three spells, and to a lesser extent four and five spells for a given wine product are identified.

To be able to describe the trade flows with more information than a mere mean or standard deviation value will allow, we also plot a descriptive survivor function. Figure 3 depicts empirical survivor functions of wine exports spells. The $\mathrm{x}$-axis plots the observed spell length, and the y-axis plots the fraction of observations whose observed spell of service exceeds a given length. The Kaplan-

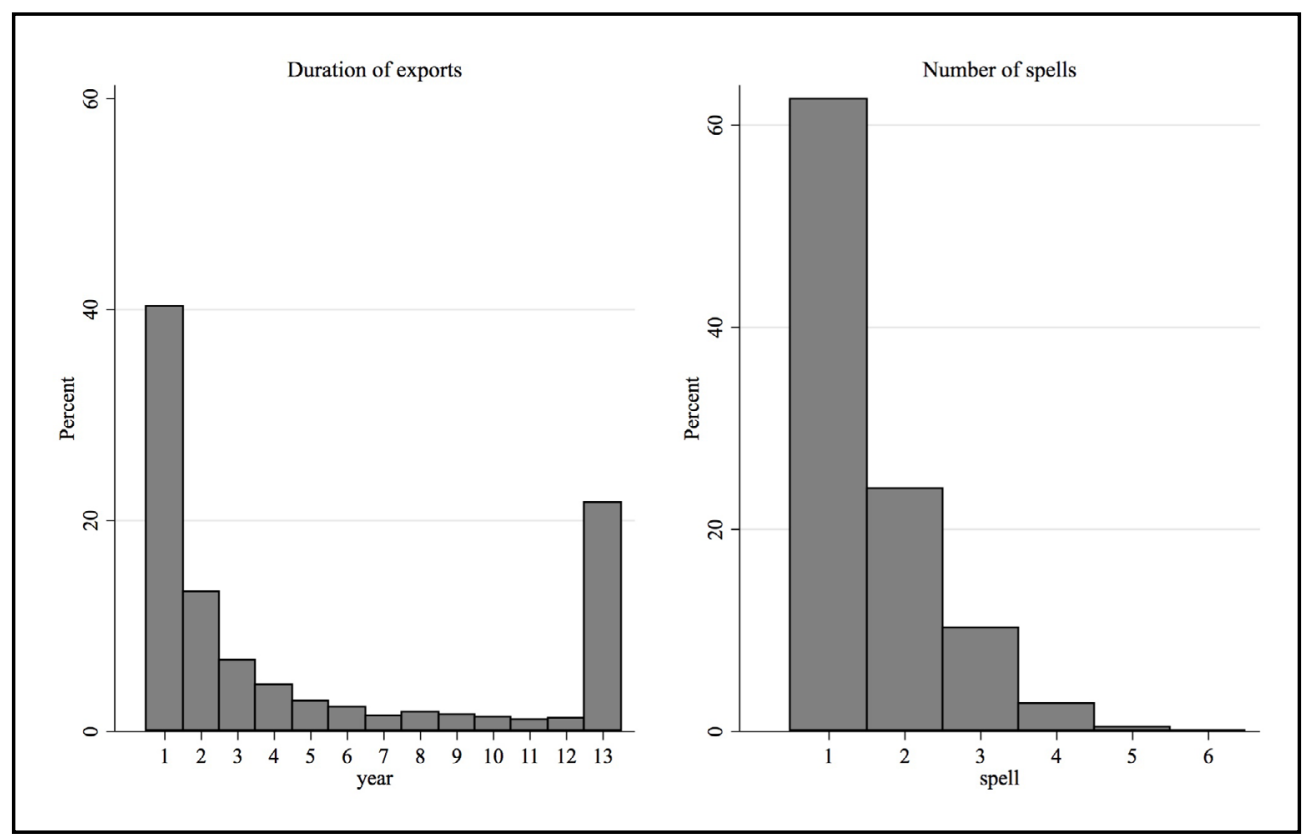

Source: Own calculations based on World Bank WITS database (2017)

Figure 2: Histograms of the number of spells and duration of the exports. 
Meier survival function indicate that in the first half of the period less than 25 per cent of spells have ceased, but this ratio has doubled in the second half of period. In other words more than $50 \%$ of all spells have ceased after economic crisis.

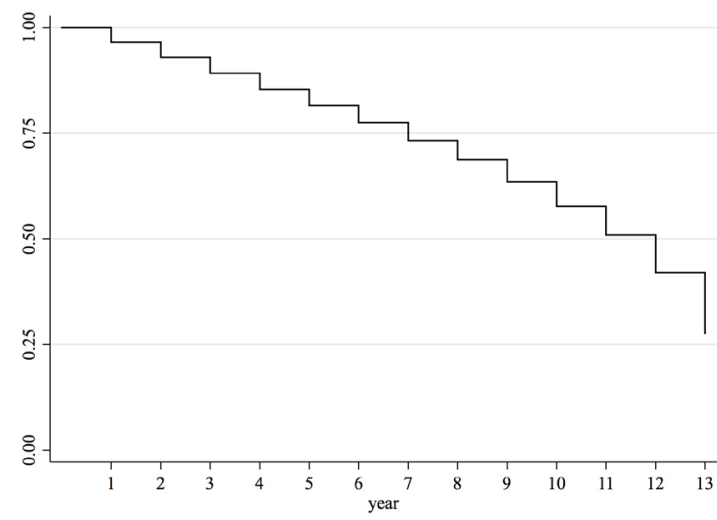

Source: Own calculations based on World Bank WITS database (2017)

Figure 3: Kaplan-Meier survival estimates.

Now we turn to determinants of duration of wine trade. First, we investigate the impact of economic crisis on the initial volume of wine export. Since we are examining a single value at the starting point of a spell, our ability to identify different effects of economic crisis is reduced. A spell either starts before or after the crisis. As a result, the impact of crisis taking effect only applies to spells starting after the crisis. We thus have two variables identifying the impacts of crisis: a dummy variable identifying the years when the agreement is in effect (crisis in effect) and a variable reflecting how long the crisis has been in effect when a spell starts.

The first and second columns of Table 2 collect the results from estimating equation (1). Using only the dummy variable identifying when the crisis is in effect we have not find significant impact. We then add the variable measuring how long the crisis was in effect when the spell started. The augmented model show that in a fixed (with respect to time) effect of the crisis decreasing initial volumes by 3,300 thousand dollars, as well as a timedependent effect which decreases initial volumes by 894 thousand dollars for every year of the crisis being in force. In other words. The impacts of economic crisis was higher by 3.5 for pre-crisis initial values than for postcrisis initial values.

We now turn to examining the impact of economic crisis on the growth of wine exports embodied in active spells. In particular, we investigate the growth of wine exports conditional on spell survival. Our results imply that the rate of growth of wine exports within a spell decreases the longer the duration of the spell, just as Besedeš et al. (2016) model predicts (third and fourth columns). Larger spells grow faster. The impacts of economic crisis are insignificant for both crisis and post-crisis dummies.

We estimate the hazard of wine exports ceasing by estimating equation (3) using random effects probit, which allows us to take into account unobserved heterogeneity. To estimate the hazard we include the standard gravity variables, GDP

\begin{tabular}{|l|l|l|l|l|l|l|}
\hline & Initial value & Initial value & growth & growth & duration & duration \\
\hline Crisis $_{\mathrm{t}}$ & 458.509 & $-3.3 \mathrm{e}+03^{* * *}$ & & $-8.9 \mathrm{e}+04$ & & $-0.121^{* * *}$ \\
\hline afterCrisis $_{\mathrm{ikt}}$ & & $-893.583^{* * *}$ & & $4.0 \mathrm{e}+04$ & & $-0.086^{* * *}$ \\
\hline Duration $_{\mathrm{ikt}}$ & & & $-1.8 \mathrm{e}+05^{* * *}$ & $-1.9 \mathrm{e}+05^{* * *}$ & $-0.110^{* * *}$ & $-0.073^{* * *}$ \\
\hline $\mathrm{X}_{\mathrm{ikt-1}}$ & & & $2.8 \mathrm{e}+05^{* * *}$ & $2.7 \mathrm{e}+05^{* * *}$ & $-0.617^{* * *}$ & $-0.609^{* * *}$ \\
\hline $\operatorname{lnGDP}_{\mathrm{it}}$ & & & & & $-0.067^{* * *}$ & $-0.064^{* * *}$ \\
\hline $\operatorname{lnGDP}_{\mathrm{kt}}$ & & & & & $-0.080^{* * *}$ & $-0.076^{* * *}$ \\
\hline lndistance $_{\mathrm{ik}}$ & & & & & $0.130^{* * *}$ & $0.125^{* * *}$ \\
\hline border $_{\mathrm{ik}}$ & & & & & $-0.167^{* *}$ & $-0.166^{* *}$ \\
\hline language $_{\mathrm{ik}}$ & & & & & $-0.079^{* *}$ & $-0.072^{*}$ \\
\hline constant & $-1.7 \mathrm{e}+06^{* * *}$ & -485.560 & $-2.7 \mathrm{e}+05^{* * *}$ & $2.7 \mathrm{e}+05^{* * *}$ & $3.153^{* * *}$ & $3.083^{* * *}$ \\
\hline $\mathrm{N}$ & 54587 & 50388 & 50388 & 50388 & 46865 & 46865 \\
\hline $\mathrm{R}^{2}$ & 0.1436 & 0.0972 & 0.2350 & 0.1658 & & \\
\hline Chi & & & & & 4183.966 & 4426.496 \\
\hline $\mathrm{Rho}^{2}$ & & & & & 0.154 & 0.149 \\
\hline
\end{tabular}

Note: $* \mathrm{p}<0.1 ; * * \mathrm{p}<0.05 ; * * * \mathrm{p}<0.01$

Source: Authors' own calculations

Table 2: Estimation results. 
of both the importer and the exporter, distance between the two, as well as a dummy indicating the existence of a common border and a common language that the two countries share. Our results indicate that the hazard are decreasing in duration, indicating that longer lived spells are less likely to cease and also grow less (fifth and sixth columns) confirming findings by Besedeš et al. (2016). The size of GDP for both exporter and importer sides decrease the probability of wine export ceasing. In addition, exports are less sensitive to the GDP of the exporting country than to the income of the importing countries. Similarly to earlier studies (Brenton et al., 2009; Hess and Persson, 2011, 2012; Besedeš et al., 2016) estimations suggest that the common border and common language decreases, whilst the distance increases the likelihood of failure in the wine export relationships in both specifications.

\section{Conclusion}

The paper analyses the impact of economic crisis on the duration of word wine exports for 40 leading wine exporter countries between 2000 and 2012. More specifically, we investigate three attributes of wine exports embodied in exports relationships: the initial value of exports, the growth of exports within a spell, and the hazard of exports ceasing. Trade relationships between the 40 leading wine exporters and their partners and are often dynamic, with numerous entry and exits and spells of service. During the 2000 to 2012 period, there were 6706 different exporter trade relationships for leading wine exporters. While two-third of these trade relationships had a single spell of service, onethird of all trade relationships have multiple spells of service. Approximately 40 per cent of all spells of service last for just a single year, and approximately 55 per cent of all spells of service last for three years or less. In line with the literature on the trade duration, we find that wine exports are rather short lived even for leading wine exporter countries. Compared with other duration studies, we find relatively longer spells of service for wine exports.

Our estimations imply that economic crisis has not significant impacts on initial value of wine export starting before crisis, whilst it has negative effects on spells beginning after crisis. Surprisingly, economic crisis does not influence the export growth, and decrease the probability of failure of wine exports. This puzzling results can be explained by quick recovery of world wine exports after economic crisis. The effects are usually smaller for spells starting after crisis. This suggests that we find two types of spells according to starting before and after crisis. Estimations indicate that longer lived spells are less likely to cease and also grow less. We find the standard "gravity" determinants of trade including market size and trade costs do affect on the export duration at the world wine market.

\section{Acknowledgments}

The author acknowledges financial support from the project NKFI-115788, „Economic Crises and International Agricultural Trade“.

\section{Corresponding author:}

Professor Imre Fertö

Institute of Economics, Centre for Economic and Regional Studies, Hungarian Academy of Sciences, H-1097

Budapest, Tóth K. u. 4. and Kaposvár University, H-7400 Kaposvár Guba S. 40, Hungary

E-mail:ferto.imre@krtk.mta.hu

ORCID: orcid.org/0000-0002-3742-5964

\section{References}

[1] Anderson, K. and Golin, G. (eds) (2004) "The World's Wine Markets: Globalization at Work", Edward Elgar: Cheltenham, UK; Northampton, MA, USA. ISBN-10: 1843764393, ISBN-13: 9781843764397.

[2] Anderson, K. and Nelgen, S. (eds) (2011) "Global Wine Markets, 1961 to 2009: A Statistical Compendium", Adelaide: University of Adelaide Press.

[3] Besedeš, T. and Prusa, T. J. (2006a) "Ins, outs and the duration of trade", Canadian Journal of Economics, Vol. 39, No. 1, pp. 266-295. E-ISSN 1540-5982. 
[4] Besedeš, T. and Prusa, T. J. (2006b) "Product Differentiation and Duration of U.S. Import Trade", Journal of International Economics, Vol. 70, No. 2, pp. 339-358. ISSN 0022-1996. DOI 10.1016/j.jinteco.2005.12.005.

[5] Besedeš, T., Moreno-Cruz, J. and Nitsch, V. (2016) "Trade Integration and the Fragility of Trade Relationships: Theory and Empirics", Manuscript

[6] Brenton, P., Saborowski, C. and von Uexküll, E. (2010) "What Explains the Low Survival Rate of Developing Country Export Flows", The World Bank Economic Review, Vol. 24, No. 3, pp. 474-499.

[7] Bojnec, Š. and Fertő, I. (2012) "Does EU enlargement increase agro-food export duration?", The World Economy, Vol. 35, No. 5, pp. 609-631. E-ISSN 1467-9701. DOI 10.1111/j.1467-9701.2012.01441.x.

[8] Cleves, M. A., Gould, W. W. and Gutierrez, R. G. (2004) "An Introduction to Survival Analysis Using STATA", Stata Press, College Station, Texas. ISBN-13: 978-1597180412, ISBN-10: 1597180416.

[9] Cadot, O., Iacovone, L., Pierola, M. D. and Rauch, F. (2013) "Success and failure of African exporters", Journal of Development Economics, Vol. 101, No. C, pp. 284-296. ISSN 0304-3878. DOI 10.1016/j.jdeveco.2012.12.004.

[10] Castillo, J. S., Villanueva, E. C. and García-Cortijo, M. C. (2016) "The International Wine Trade and Its New Export Dynamics (1988-2012): A Gravity Model Approach", Agribusiness, Vol. 32, pp. 466-481. DOI 10.1002/agr.21463.

[11] Dal Bianco, A. Boatto, V. L., Caracciolo, F. and Santeramo, F. G. (2016) "Tariffs and non-tariff frictions in the world wine trade", European Review of Agricultural Economics, Vol. 43, No. 1, pp. 31-57. DOI 10.1093/erae/jbv008.

[12] Feenstra, R. C. and Rose, A. K. (2000) "Putting things in order: Trade dynamics and product cycles", Review of Economics and Statistics, Vol. 82, No. 3, p. 369-382. E-ISSN 1530-9142, ISSN 0034-6535.

[13] Fertő, I. and Soos, K. A. (2009) "Duration of trade of former communist countries in the EU market", Post-communist economies, Vol. 21, No. 1, p. 31-39. DOI 10.1080/14631370802663604.

[14] Fertö, I., Podruzsik, S. and Balogh, J. (2016) "Intra-industry trade in the wine sector in the enlarged European Union", Review of Agricultural, Food and Environmental Studies, No. 97, Vol. 3, pp. 159-172. E.ISSN 2425-6897, ISSN 2425-6870.

[15] Hess, W. and Persson, M. (2011) "Exploring the duration of EU imports", Review of World Economics, Vol. 147, No. 4, pp. 665-692. E-ISSN 1610-2886, ISSN 1610-2878.

[16] Hess, W. and Persson, M. (2012) "The duration of trade revisited. Continuous-time versus discretetime hazards", Empirical Economics, Vol. 43, No. 3, pp. 1083-1107.

[17] Haveman, J. and Hummels, D. (2004) "Alternative hypotheses and the volume of trade: the gravity equation and the extent of specialization", Canadian Journal of Economics, Vol. 37, pp. 199-218. E-ISSN 1540-5982. DOI 10.1111/j.0008-4085.2004.011_1.x.

[18] Jaud, M. and Kukenova, M. (2011) "Financial development and survival of African agri-food exports", Policy Research, Working Paper 5649. Washington, DC: World Bank.

[19] Lombardi, P., Dal Bianco, A., Freda, R., Caracciolo, F. and Cembalo, L. (2016) "Development and trade competitiveness of the European wine sector: A gravity analysis of intra-EU flows", Wine Economics and Policy, Vol. 5, No. 1, pp. 50-59. ISSN 2212-9774. DOI 10.1016/j.wep.2015.12.002.

[20] Mariani, A., Napoletano, F., Pomarici, E. and Vecchio, R. (2012) "Tariff and non-Tariff Barriers to Wine Exports and Initiatives to Reduce their Effects", Agricultural Economics Review, Vol. 15, No. 1, pp. 5-24. ISSN 1109-2580.

[21] Mariani, A., Pomarici, E. and Boatto, V. (2012) "The international wine trade: Recent trends and critical issues", Wine Economics and Policy, Vol. 1, No. 1, pp. 24-40. ISSN 2212-9774. DOI 10.1016/j.wep.2012.10.001. 
[22] Mayer, T. and Zignago, S. (2011) "Notes on CEPII's distances measures: The GeoDist database", CEPII Working Paper 2011- 25 , December 2011, CEPII.

[23] Nguyen, D. X. (2012) "Demand Uncertainty: Exporting Delays and Exporting Failures", Journal of International Economics, Vol. 86, No. 2, pp. 336-344. ISSN 0304-3878, DOI 10.1016/j.jinteco.2011.10.007.

[24] Nitsch, V. (2009) "Die another day: Duration in German import trade", Review of World Economics, Vol. 145, No. 1, pp. 133-154. E-ISSN 1610-2886, ISSN 1610-2878.

[25] Obashi, A. (2010) "Stability of production networks in East Asia: Duration and survival of trade", Japan and the World Economy, Vol. 22, No. 1, pp. 21-30. ISSN 0922-1425. DOI 10.1016/j.japwor.2009.06.002.

[26] World Bank (2017a) "Commodity Trade Database (COMTRADE)", Washington D.C. Available through World Bank's World Integrated Trade Solution (WITS) software [Online]. Available: http://www.wits.worldbank.org. [Accessed: 15 Aug 2017].

[27] World Bank (2017b) "World Development Indicators", Washington, D.C. [Online]. Available: http://data.worldbank.org/indicator. [Accessed: 20 Aug 2017]. 